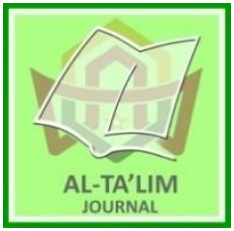

AL-TA'LIM JOURNAL, 26 (2), 2019, (112-120)

(Print ISSN 1410-7546 Online ISSN 2355-7893)

Available online at http://journal.tarbiyahiainib.ac.id/index.php/attalim

\title{
The Development of Students' Worksheet on Students' Creative Thinking Skill
}

Received: $09^{\text {th }}$ December 2018; Revised: $14^{\text {th }}$ July 2019; Accepted: $30^{\text {th }}$ July 2019

Permalink/DOI: http://dx.doi.org/10.15548/jt.v26i2.541

\section{Abdul Bashith*) \\ Universitas Islam Negeri Maulana Malik Ibrahim Malang, Indonesia \\ E-mail: abbash98@pips.uin-malang.ac.id}

\section{Saiful Amin}

Universitas Islam Negeri Maulana Malik Ibrahim Malang, Indonesia

E-mail: amin.geo87@pips.uin-malang.ac.id

\section{Ravinesh Rohit Prasad}

Ministry of Education of Fiji Island, Suva, Republic of Fiji

e-mail: prasadraro2@gmail.com

\section{Denanda Mei Dwi Kidzikri}

Universitas Islam Negeri Maulana Malik

Ibrahim Malang, Indonesia

E-mail: denandadwiki@gmail.com

\section{*) Corresponding Author}

\begin{abstract}
This study aims to 1) explain the development products of Student Worksheet on Student's creative thinking Skill; 2) describe the validity product of student Worksheet on Student's creative thinking Skill; and 3) describe the influence of student worksheet on Student's creative thinking Skill. The method in this study used to research and development (R\&D) the model of $\mathrm{R} \& \mathrm{D}$ in this study using Borg \& Gall. The analysis used in the study of development technique has three of them, a review of the learning contents, descriptive analysis, and the analysis of the test results. The development of learning materials in the form of student worksheet of creativity proved can improve the process creative thinking skill of grade V SDN Tambak Asri 02 Malang. Suggestions for optimizing the utilization of materials development is 1) the development of learning materials can utilized as references for educators. 2) Learning materials that have been developed this for more good news can be integrated with the Quran or the Hadith perspective.
\end{abstract}

Keywords: The development; students' worksheet; students' creative thinking skill

How to Cite: Bashith, A., Amin, S., Prasad, R., \& Kidzikri, D. (2019). The development of students' worksheet on students' creative thinking skill. Al-Ta Lim Journal, 26(2). doi:http://dx.doi.org/10.15548/jt.v26i2.541

\section{INTRODUCTION}

Every human being has created nature in them since she was born. Allah said in the Qur'an Surah Ar-Ruum verse 30 reads, "then the face is your face with a straight right to the religion of God; (keep on reading) nature God created man for ah te; according to the nature of it, there is no change like God. That's) the straight religion; but most of humanity know not". Of the verse, it is clear that Islam looks at the concept of a child as a human being has an innate (essential ability) that are similar to each other. The elderly and the environment became instrumental in developing the potential of children.

Creativity is the result of interaction between the individual and the environment (Al-Hajaj \& Abu, 2010). One can also influence and influenced by the context in which it located; thus, both the changes within individuals and the environment can support or inhibit creative endeavors (Saputra, 2015). The implication is that artistic ability can improve through education. It means a 
pleasant atmosphere, such as the institution of the school as one of the instruments of real student creativity (Utami, Sumarmi, Ruja, \& Utaya, 2016). The school environment is expected to build private students to become better and create a child who has a strong personality.

At the time of the children (aged 0-6 years), children exposed to psychological development regarding a sense of trust in others, think independently, and to develop initiatives (creating handicraft) (Amarta, 2012). If the child at that time failed in developing that kind of mental attitude, then; as a result, children suffer from self-doubts on others, being shy, and lacking initiative (Nursofah, Komala, \& Rusdi, 2018). A further personal failure on the childhood of this kind is undoubtedly harmful to the child's development (Herman, 2016).

From the above statement, we can imagine that in an educational institution, we should be able to provide educational services to the needy (students) well. Because of the absence of coordination or arrangement of the various systems, we cannot give in to the glaring discrepancy in any needs that can meet. The success of the learning system is the achievement of learning objectives (Rochmad, Agoestanto, \& Kharis, 2018). Furthermore, who is expected to achieve that goal? The need to accomplish that goal is students who as a subject of study. So thus, the primary goal is student success learning system to achieve that goal (Ibrahim \& Irawan, 2015). One of the factors of success in a learning activity is the existence of learning materials that support to achieve an appropriate learning objective (Arini, 2017). Learning materials are materials or content that must be mastered by students through learning activities (Ülger, 2016). Learning materials can also interpret as a medium that can accompany students on the attainment of learning objectives (Suprihatiningrum, 2013). Understanding of students in learning can be less because in SDN Tambak Asri 02 Malang, especially in $\mathrm{V}$ grade still really on one type of book learning alone.
Based on observations in SDN Tambak Asri 02 Malang, that students in the classroom already contained a creative approach on them. The student worksheet is the way researchers to improve thinking ability existing students in original. There are still shortcomings that need to be corrected, namely student worksheets, in general, have not been able to improve student creativity (Prastowo, 2012). According to the results of the interviews used, it still has drawbacks 1) student worksheet to be used only from one source. 2) Student worksheet as a lack of practice. 3) Design is a student worksheet as less attractive.

From these problems, researchers want to develop is student worksheet as used by teachers and students of class V SDN Tambak Asri. The student worksheet can enhance creative thinking in students without eliminating the primary learning objectives, i.e., increase the results of student learning (Khabibah, Jalmo, \& Suyatna, 2018). Children are great impersonator; if they already have an Idol, then the child will want to mimic what is done by his idol. It would be dangerous if they follow is not the right person (Febriani, Sudomo, \& Setianingsih, 2017). The existence of the student worksheet focuses on developing students' creativity (Luthfiana, Ambarita, \& Suwarjo, 2018). Researchers expect any change the personality of the students become better for their lives because they have only been able to follow others. There is no desire to be the pioneers of late as well as the environment of their own (Arsyad, 2012).

This study aims to 1) explain the development products of Student Worksheet on Student's creative thinking Skill. 2) Describe the validity product of student Worksheet on Student's creative thinking Skill. 3) Illustrate the influence of student worksheet on Student's creative thinking Skill.

\section{METHOD}

The method in this study used to research and development is a method used to 
produce a particular product, and test the effectiveness of these products (Sugiyono, 2011). The model of R\&D in this study using Borg \& Gall, there were 10 steps of research and development (Setyosari, 2010) is as follows: 1) research and collection of information beginning; 2) planning; 3) the development of early product formats; 4) test products; 5) a revision of the product; 6) field trials; 7) a review of the product; 8) field test; 9) the revision of the final product; and 10) dissemination and implementation.

Field studies conducted aiming to identify the behavior and characteristics of grade V SDN Tambak Asri 02 Malang. Analyzing learning students, learning difficulties, and analyze the needs of learning materials learning thematic theme eight subthemes 1 grade V SD/MI this Activity. Field trials are taken from the students of classes V SDN Tambak Asri 02 Malang totaling 26 students. Instruments in data collection consisting of interview results and tests of increasing student creativity (Arief, 2007). The analysis used in the study of development technique has three of them, a review of the learning contents, descriptive analysis, and the analysis of the test results (Soyadi \& Birgili, 2015).

\section{RESULT AND DISCUSSION}

\section{Description of the Development Result}

\section{The Part of Pre-Introduction}

The pre-introduction part consists of 1) front cover; 2) back cover; 3) Foreword; 4) Basic Foundation of creativity; 5) Surplus Materials; 6) KD, KI, and Indicators; 7) Guidelines the use of Learning Materials; 8) Table of Contents.

Front cover of learning materials consists of the name of the compiler, jails materials namely thematic books. Learning materials tailored to the title subject matter developed. They have entitled "Environmental Friend," background materials suited to the purpose of these materials created. It intended so that readers can find out the meaning of the title before opening the contents of such documents.

Back cover designed simple containing title, explanation of globally linked with learning materials and exciting things contained in it - besides, some supporting images of the content, and developer examples located at the bottom. The preface is placing on the home page as the author's communication with readers welcome. As for the content of the foreword is a praise to God Almighty, the destination he arranges materials book form, an explanation related to the content of the book, and the expectations of constituents against the book developed.

The prominence of learning materials expose about the various advantages of this book compared to the other elements, making learning materials in the form of the book can be accepted as learning materials. The necessary foundation of creativity presented an explanation of the necessity of developing the potential of children, i.e., one of which is the potential of their creativity, reinforced with A word in the Qur'an in Surat Ar-Rum verse 30 .

Essential competencies, core competencies, and the indicators of achievement used as a reference in the implementation of learning activities. Materials usage guidelines include a description of each of the sections contained in the materials. It hoped the presence of these guidelines could make it easier for students to understand the context of a description of the material in each study (Awang \& Ramly, 2008). The table of contents contains chapters and sub-chapters that will be filled in the page and includes a list of pages of all parts of the learning material. That is to make it easier for readers to find things to learn.

\section{Introduction}

The introduction materials located at the beginning of the learning activities, to provide related information material to be learned. Icon image in the middle of the equipment adapted to the bottom, to bridge 
the readers before entering the more excellent learning material.

\section{Section Content}

And the "Let's Read," of the students were asked to read a nonfiction text story. Although the development of learning materials aimed at improving the creative thinking of students' researchers, do not eliminate the thematic learning objectives.

\section{Supplementary Parts}

The following are the components of corresponding parts, namely: Musings: The piece is located in the content section of Musings with intent when students are learning, so students simultaneously earn a spiritual component is in this student worksheet. 2013 curriculum should not separate from this religious aspect, reinforced by Islamic University, which plays an important role, would be the occurrence of product development.

Andaikata: If a part of located on the end of a reading, the purpose of the creation of this student worksheet is to increase students ' creative thought process, and a question of precedence by the word "Andaikata" proved to be practice students in degrading potential creativity in their answer.

Creative Techniques: Creative techniques is an effort of researchers to train students ' right to improve their creative thought process. Innovative technology is at the bottom of the reading that can increase the knowledge of students or teachers.

Let's Learn: So keep learning the plot and not just focus on improving student skills. The teacher still supports KI, KD, and learning indicators selected in book K13.

Test Capabilities: Test capabilities or competence contains the evaluation questions ranging from early learning to learning at the end of this book. In this section, students answer the questions asked to measure students who will discuss the material presented. Besides that, it is to learn about the renewal process that they are doing for previously ongoing learning. The evaluation questions arranged in the form of statements and answers shaped paragraphs.

Bibliography: The bibliography contains a list of references or sources of reference book used by the compiler as a source of materials for preparing the booking form. In addition to that, as evidence that the contents of the amplifier have a rationale. Students can find a list of other references listed in the bibliography. The purpose of the presence of such texts is so that students or teachers knowing the sources references taken compilers in making learning materials.

\section{Data Validation}

In this study, data obtained there are two kinds of data, i.e., the qualitative and quantitative data. Quantitative data derived from the question form an assessment using the Likert scale, while the qualitative data in the form of critiques and suggestions from the validation - the acquisition of such data through a two-stage evaluation, i.e., validation experts and field test. Data validation was carried out by three valuators' consisting of content, design, and learning experts.

\section{The Results of Content Validation}

Based on the counting of the observations made by the expert, the contents is as a whole reached $90 \%$. If eligibility criteria are reviewed based on the table, then this score is included in the requirements for valid or worthy. However, to optimize product developed researchers must revise some parts of the materials if they need to replace. Has written that there is some aspects that need to fix that products are developed are more qualified.

\section{The Results of Design Validation}

Based on the counting of the observations made by the expert, the contents is as a whole reached $90 \%$. If eligibility criteria are reviewed based on the table, then this score is included in the requirements for valid or worthy (Arikunto, 2003). However, 
to optimize product developed researchers must revise some parts of the materials if they need to replace. Based on the criticism and suggestions, has written that some parts need improvement so that it becomes more of a maximum of its utilization.

\section{The Results of Study Validation}

Based on the counting of the observations made by the expert, the contents is in $91.6 \%$. If eligibility criteria are reviewed based on the table, then this score is included in the requirements for valid or worthy to be used.

As for qualitative data derived from comments and expert advice, the students worksheet that has already been made fit with existing learning content on the theme 8 . The cover design or layout is also attractive and by existing topics in it and can make children don't get bored. Although the exercises are a bit confusing because it looks matter not familiar, so teachers need to hang back, students already according to improve the creativity of students ".

\section{The Result of Experiment Test}

Data validation obtained from the results of the trial against the learning materials at 26 grades V SDN Tambak Asri 02 Malang. Based on the above calculation, there is then retrieved the overall reach field test 80.8. If eligibility criteria are reviewed based on the table, the above score should be included in the requirements for valid or viable for use in learning.

\section{Student's Creative Thinking Skill}

Following the percentage of the pretest and posttest data of grade $\mathrm{V}$, it was found that in the trials to find ou the difference of creative thinking of students before and after using the product. Calculation based on the average by using equations above indicates that the average value of pre-test was 65.37 , and the average cost of post-test was 85.5. The average price of these students can be seen based on the number of averages or the average post-test, which is 85.5 more significant than the smaller pre-test values, which is 65.37. It shows that there is a substantial increase in the increase of 20.13. Students experience increased artistic thinking ability using the student worksheet creativity so that students can learn about creative thinking in class V.

The results of the above calculation show that $t_{\text {count }}$ is greater than $t_{\text {table }}$, so $\mathrm{H}_{\mathrm{o}}$ accepted and $\mathrm{H}_{\mathrm{a}}$ rejected (Hamdani, 2011). So there are significant differences between levels of creative thinking of students before using and after using the student worksheet creativity on thematic learning class $\mathrm{V}$ theme eight sub-theme 1.

Next than average known that $\mathrm{X}_{2}$ is higher in value than the $X_{1}(2,92>1,708)$. It indicates that the results of the post-test are higher than in the pre-test. So, it can infer that the learning materials in the form of the student learning worksheet on the thematic learning theme eight sub-themes 1 class $\mathrm{V}$ $\mathrm{SD} / \mathrm{MI}$. It was developed to increase creative thinking grade $\mathrm{V}$ in SDN Tambak Asri 02 Malang.

\section{The Analysis of Student Worksheet Thematic}

The product development produced is a learning media consisting of student work Thematic themes of the combination of subthemes one. This product supports students and teachers' learning in the $\mathrm{V}$ grade teaching thematic education at SDN Tambak Asri 02 Malang to improve student creativity. Learning media development products are present in the form of thematic student worksheets. This product development aims to meet the availability of supplementary books that can increase effectiveness and attract students in learning thematic learning with the 2013 curriculum.

Whereas the procedure of the development of learning materials is through several stages, including 1) Pre-trial stage of development. 2) Development stage traveled with researchers conducting the preparation of products from materials that had obtained and also the results of the analysis. 3) Test 
validation and revision stages of product development (Payudi, Ertikanto, Fadiawati, \& Suyatna, 2017).

Product development of learning materials that researchers develop includes material water cycle and non-fiction stories. Test competencies in product development have a similar problem that is package in the form of descriptions and troubleshooting. It is deliberately drawn up to improve creative thinking of student (Gregory, Hardiman, Yarmolinskaya, Rinne, \& Limb, 2015). The existence of these materials can use as an alternative or supplementary learning materials for educators and students in addition to the elements already used in the previous study (Astutik \& Susantini, 2017).

\section{The Analysis of Expert Validation}

\section{Content Validation}

Based on the results of the expert assessment of the contents of the retrieved $95 \%$, the percentage of the final rate of the achievement of the qualification is valid or worthy of use $(79 \%<$ score $\leq 100 \%)$. Media worksheets for class $\mathrm{V}$ Thematic students SD/MI 8 sub-themes one theme according to content that is valid and feasible to use. The feasibility is because it is following the standard curriculum, Competence, Basic Competence, learning objectives and Indicators with the material in the book. So too with the components of the content in the form of the compatibility of the material presented on the development of learning materials, compliance with core competence indicators, accordance with the necessary competence of conformity indicator systematic learning content descriptions, clarity exposure to the document, a substance that can motivate students, presented a summary of the article in accordance with the deliberations of the evaluation instruments, precision used can measure students ' ability, ease of language used in learning materials (Özmen \& Yildirim, 2005).

\section{Design Validation}

Based on the results of the expert assessment of the percentage obtained $90 \%$ design, the rate of achievement the qualifying data valid or worthy of use $(79 \%<$ score $\leq$ 100\%). Expert assessment of the model seen from several aspects, the first is the assessment of cover, the cover of votes already exciting and in line with the content of the material because according to the design of colors used is just right and not too turned on, the picture on the cover has also been adapted to the book title, i.e., the theme is "environment is our friend", the use of fonts and any size is just right so that rated the book looks interesting to read and learn.

The use of the model and the size of the letters comply yet grade $\mathrm{V}$, because of the messages readable. All the letters using models of different size and color Desai to the characteristics of elementary school students. The overall layout of the book exciting and valued by the inhabitants on the level of primary school children, because children love with something that makes them interested.

\section{Learning Validation}

Based on the results of the expert assessment of learning, i.e., master class $\mathrm{V}$ SDN Tambak Asri 02 Malang, the percentage obtained is $91.6 \%$. The rate of the achievement of the qualification is valid or worthy to be used $(79 \%<$ score $\leq 100 \%)$. According to the opinion of the expert study, learning materials in the form of Thematic books are said to be feasible. The article was presented already by the curriculum of 2013, the essential competencies, core competencies, and indicators. Overall materials used have been very fit with the content and learning objectives that will be achieved and by the capabilities of the reasoning child so that the child is motivated to learn more about the material that has presented.

\section{The analysis of Student's Creative Thinking Skill}

Evaluation of the enhancement of the creative thinking of students is carried out to monitor the process, progress, and improvement of creative thinking of students, 
on an ongoing basis (Fakhriyani, 2016). As such, then the evaluation should be done in teacher learning continue, not just on the seasons or scheduled repeat exams only (Torrance, 1984).

It can be said that this Thematic book learning media capable of effectively can improve creative thinking ability of the students of classes $\mathrm{V}$ because this student worksheet Thematic in design based on characteristics of the user so that the students can use independently and facilitate students in learning that has been tested to its an invalid by some expert validation.

Research generates $t_{\text {calculate }}=2.92>$ $\mathrm{t}_{\text {table }}=1.708$. Thematic book learning materials that have been developing have a good level of relevance to the curriculum, learning materials material easy to understand, the simple language used as well as the appropriate instances and close to the lives of students. The results of the development that has done can increase creative thinking of students

According to Freud, people are just encouraged to be creative if they cannot meet the needs of sexual directly (Sandika \& Fitrihidajati, 2018). At the age of four years on child physical cravings arise against the parents of different gender (Utami et al., 2016). Because these needs cannot meet, then it happens early and sublimation of the imagination. So according to Freud's creativity can be formed by one's gender needs since they are still small, and other theories also support the hypothesis, i.e., methods that say that Kris is their most can "calling" materials from nature the unconscious mind.

But both the theory is contradicted by the argument made by Jung, Jung believed that nature was the one who played the role of the unconscious which is very important in the appearance of a high level of creativity (Yusnaeni, Corebima, Susilo, \& Zubaidah, 2017). It is therefore essential to provide a directional experience to learners (learning media gives the right) so that the learners can thrive better (Zubaidah, Fuad, Mahanal, \& Suarsini, 2017).

\section{CONCLUSION AND RECOMMENDATION}

The development of learning materials in the form of student worksheet of creativity on thematic learning theme eight sub-theme 1 to grade $\mathrm{V}$ SD/MI proved can improve the process creative thinking skill of grade $\mathrm{V}$ SDN Tambak Asri 02 Malang.

Suggestions for optimizing the utilization of materials development is as follows: 1) The development of learning materials can utilize as references as well as grip thematic materials for class V SD/MI and also educators; 2) Students can use the development of learning materials without accompanied by a teacher; and 3) Learning materials that have been developed this for more good news can be associated more with the approach of the Quran or the Hadith to guide students ' mindset that there is a correlation between the importance of having a personal creative with teachings that have to write in the Al-Quran. The presence of a new approach to the Quran and the Hadith are expected not only to guide students to think globally but can also form the moral character of students in applying the knowledge they have learned.

\section{REFERENCES}

Al-Hajaj, \& Abu, Y. (2010). Kreatif atau Mati. Solo: Ziyad Visi Media.

Amarta, R. (2012). Agar Kamu Menjadi Pribadi Kreatif. Yogyakarta: Sinar Keroja.

Arief. (2007). Pengantar Penelitian dalam Pendidikan. Yogyakarta: Pustaka Pelajar.

Arikunto, S. (2003). Dasar-Dasar Evaluasi Pendidikan. Jakarta: Bumi Aksara.

Arini, W. (2017). Analisis Kemampuan Berpikir Kreatif pada Materi Cahaya Siswa Kelas Delapan SMP Xaverius Kota Lubuklinggau. SPEJ (Science 
Abdul Basith, Saiful Amin, Revinesh Rohit P, Denanda Mei DK: Development of Students'... | 119

and Physics Education Journal), 1(1), 23-38.

https://doi.org/10.31539/spej.v1i1.41

Arsyad, A. (2012). Media Pembelajaran. Jakarta: PT Raja Grafindo Persada.

Astutik, S., \& Susantini, E. (2017). Effectiveness of Collaborative Students Worksheet to Improve Student's Affective Scientific Collaborative and Science Process Skills (SPS). 5(1), 14.

Awang, H., \& Ramly, I. (2008). Creative Thinking Skill Approach Through Problem-Based Learning: Pedagogy and Practice in the Engineering Classroom. International Journal of Educational and Pedagogical Sciences, 2(4), 6.

Fakhriyani, D. V. (2016). Pengembangan kreativitas anak usia dini. Wacana Didaktika, 4(2), 193-200.

Febriani, S., Sudomo, J., \& Setianingsih, W. (2017). Development of Student Worksheet Based on Problem Based Learning Approach to Increase 7th Grade Student's Creative Thingking Skills. Journal of Science Education Research, 1(1). https://doi.org/10.21831/jser.v1i1.161 79

Gregory, E., Hardiman, M., Yarmolinskaya, J., Rinne, L., \& Limb, C. (2015). Building Creative Thinking in the Classroom: From Research to Practice. Baltimore: Johns Hopkins University.

Herman, T. (2016). The Enhancement of Students' Creative Thinking Skills in Mathematics through The 5E Learning Cycle with Metacognitive Technique. International Journal of Education and Research, 4(7), 14.

Ibrahim, M., \& Irawan, A. (2015). Effectivity of Peer Tutoring Learning to Increase Mathematical Creative Thinking Ability of Class XI IPA SMAN 3

Kendari 2014. International Journal of Education and Research, 3(1), 16.

Khabibah, N., Jalmo, T., \& Suyatna, A. (2018). The Use Of Inquiry-Based Student Worksheet To Instills Science Generic Skill Of The Students. International Journal of Research GRANTHAALAYAH. https://doi.org/10.5281/zenodo.13011 76

Luthfiana, A., Ambarita, A., \& Suwarjo, S. (2018). Developing Worksheet Based on Multiple Intelligences to Optimize the Creative Thinking Students. JIPM (Jurnal Ilmiah Pendidikan Matematika), $\quad 7(1), \quad$ 1-12. https://doi.org/10.25273/jipm.v7i1.243 0

Nursofah, N., Komala, R., \& Rusdi, R. (2018). The Effect of Research Based Learning Model and Creative Thinking Ability on Students Learning Outcomes. Indonesian Journal of Science and Education, 2(2), 168173. https://doi.org/10.31002/ijose.v2i2.58 4

Özmen, H., \& Yildirim, N. (2005). Effect of Work Sheets on Student's Success: Acids and Bases Sample. Journal of TURKISH SCIENCE EDUCATION, 4.

Payudi, P., Ertikanto, C., Fadiawati, N., \& Suyatna, A. (2017). The development of student worksheet assisted by interactive multimedia of photoelectric effect to build science process skills. International Journal of Science and Applied Science: Conference Series, 2(1), 273-282. https://doi.org/10.20961/ijsascs.v2i1.1 6726

Prastowo, A. (2012). Panduan Kreatif Membuat Bahan Ajar Inofatif. Yogyakarta: I Diva Press.

Rochmad, Agoestanto, A., \& Kharis, M. (2018). Characteristic of critical and creative thinking of students of 
mathematics education study program. Journal of Physics: Conference Series, $\quad 983, \quad 012076$. https://doi.org/10.1088/17426596/983/1/012076

Sandika, B., \& Fitrihidajati, H. (2018). Improving creative thinking skills and scientific attitude through inquirybased learning in basic biology lecture toward student of biology education. Jurnal Pendidikan Biologi Indonesia, 4(1), 23. https://doi.org/10.22219/jpbi.v4i1.532 6

Saputra, Y. W. (2015). Pengembangan Bahan Ajar Geografi pada Kompetensi Dasar Memahami Atmosfer dan Dampaknya terhadap Kehidupan di Muka Bumi Kelas X SMA/MA Semester II dengan Menggunakan Pendekatan Keruangan. Jurnal Pendidikan Geografi: Kajian, Teori, Dan Praktek Dalam Bidang Pendidikan Dan Ilmu Geografi, 20(2), 53-60.

https://doi.org/10.17977/jpg.v20i2.293

Setyosari, P. (2010). Metode Penelitian Pendidikan Dan Pengembangan. Jakarta: Prenada Media.

Soyadi, Y., \& Birgili, B. (2015). Creative and Critical Thinking Skills in Problembased Learning Environments. Journal of Gifted Education and Creativity, 2(2), 71-71. https://doi.org/10.18200/JGEDC.2015 214253

Sugiyono. (2011). Metode Penelitian Kuantitatif Kualitatif dan $R \& D$. Bandung: Alfabeta.
Suprihatiningrum, J. (2013). Strategi Pembelajaran Teori \& Aplikasi. Yogyakarta: Ar-ruzz Media.

Torrance, E. P. (1984). Torrance Tests of Creative Thinking. Bensenville: Scholastic service.

Ülger, K. (2016). The Relationship between Creative Thinking and Critical Thinking Skills of Students. Hacettepe University Journal of Education, 1-1. https://doi.org/10.16986/HUJE.20160 18493

Utami, W. S., Sumarmi, Ruja, I. N., \& Utaya, S. (2016). The Effectiveness of Geography Student Worksheet to Develop Learning Experiences for High School Students. Journal of Education and Learning, 5(3), 315. https://doi.org/10.5539/jel.v5n3p315

Yusnaeni, Corebima, A. D., Susilo, H., \& Zubaidah, S. (2017). Creative Thinking of Low Academic Student Undergoing Search Solve Create and Share Learning Integrated with Metacognitive Strategy. International Journal of Instruction, 10(2), 245262.

Zubaidah, S., Fuad, N., Mahanal, S., \& Suarsini, E. (2017). Improving Creative Thinking Skills of Students through Differentiated Science Inquiry Integrated with Mind Map. Journal of TURKISH SCIENCE EDUCATION, 14.

https://doi.org/10.12973/tused.10214a ) 